\title{
An evaluation of the risk profile of the banking industry in Ghana and its implication on the national economy
}

\author{
Ransford Quarmyne Churchill \\ Department of Accountancy, Accra Polytechnic, Ghana
}

\section{Email address:}

ransfordchurchill@yahoo.co.uk

To cite this article:

Ransford Quarmyne Churchill. An Evaluation of the Risk Profile of the Banking Industry in Ghana and its Implication on the National Economy. International Journal of Economics, Finance and Management Sciences. Vol. 1, No. 6, 2013, pp. 367-373. doi: $10.11648 /$ j.ijefm.20130106.23

\begin{abstract}
The banking system is central to the economic management of every country. The impact of the global financial crisis and developments in some economies therefore call for a thorough assessment of the risk management framework of the Ghanaian banking sector. The main theme that runs through this study is the assessment of the risk profile of the Ghanaian banking industry and the potential effects of any mismanagement of the sector, on the economy. The study exposits on risk management in the banks as theoretical framework. Then, on the strength of analytical tools as trend analysis, benchmarks and charts, it analyzes available records between 2007 and 2012 to assess the sector in the areas of balance sheet items, credit, market and operational risks standards in the sector. It as well uses the level of implementation of the BCBS accords as a yardstick to infer the sector's risk profile and evaluates the implications of non-adherence to the recommendation therein. It settles on the note that despite the good risk standards in the areas of capital adequacy, sound liquidity ratio and profitability of the industry, the high rate of Non-Performing Loan, the cedi instability, the inadequacy of the implementation of the Basel accords and operational deficiencies presents yet the weakness of the sector that vitiates the risk stature of the sector. On the balance of probability therefore, the sector generally does not have the best risk profile. There is therefore the need to keep a keen eye on the sector as any untoward developments in the sector could easily spillover to affect the national economy.
\end{abstract}

Keywords: Risk, Basel Committee, Banking, Supervision, Economy, Growth, Non-Performing Loans, Ghana

\section{Introduction}

The financial sector of every economy is the pivot on which the economy revolves and one crucial player in the sector is the bank. Hence, the level of resilience of any economy largely depends on how strong its banking industry is. Economic downturns in countries have almost always been the consequences of imprudent management of the banking sector. It is on records that between the period of 1970 - 1999, there were 113 banking crisis affecting a number of counties leading to the loss of hundreds of billions of dollars. Some of the economies which were affected by these bank crisis, recorded in recent history include; the United States, Japan, China, Argentina, Indonesia, Finland, Sweden and Norway (Böblingen, 2008).

The resilience shown by the Ghanaian economy in recent times has attracted a lot of investments into the country. Many new banks have emerged; some of whom are the offshoots of some international banks; including those who ventured out of the Nigerian system, while others are newly established Ghanaian bank. The investment in the financial sector is largely viewed as a further boost for the economic growth of the country which has just attained a middle income country status. However considering the factors that led to the emergence of the Nigerian banks in the country and the fact that the Bank of Ghana has also called for the recapitalization of banks in a similar fashion to the Nigerian episode, it would be naturally prudent to be concerned about how to avert the possibility of an experience in the country that is akin to the Nigerian episode; to keep the clock of progress ticking in the Ghanaian economy. Hitherto, the banking sector has been quite conservative in operation however with the advent of the new breed of banks with more forceful business orientation into the economy; the outlook of the banking sector has altered quite considerably. An era of intense competition has engulfed the sector which has sparked off a new regime that is using all sorts of incentives to woo both 
customers and professionals in the industry. There is high staff mobility within the industry which is induced by attractive remunerations and the promise of higher position that barely takes into consideration the competence level and abilities of such staff to manage the high offices. Again, the development in the sector could also be a temptation for banks to over-step the boundaries of banking regulations. This fear might be bolstered by a recent report by the Bank of Ghana (GNA Report, July 24, 2012) which cited the Access Bank Ghana Limited for sanctions on the account of impropriety in foreign operations dealings in contravention of Act 723, 2006. These factors give further cause for concerns for one to assess whether there are really enough safeguards to arrest the canker that could destroy the banking sector in Ghana. Again, there are regular publications of fraud ( $\&$ disclaimers) cases which also include staff of banks as well as litigations in court between banks and other parties with regard to breach of contract.

The above notwithstanding, one might also not be far from right to say, although the just ended recapitalization exercise undertook by the Bank of Ghana could be a shield for the capital inadequacy such as the one that led to collapse of the Ghana Co-operative Bank and the Bank for Housing and Construction; considering the commonalities that exist between the action and a similar measure taken by the Nigerian central bank, one is tempted to question the risk preparedness of the Ghanaian banks in the face of all these potential risks.

\section{Literature Review}

\subsection{Risk Management in Banking}

Risk management is described as the performance of activities designed to minimise the negative impact (cost) of uncertainty (risk) regarding possible losses (Schmidt and Roth, 1990). Redja (1998) also defines risk management as a systematic process for the identification and evaluation of pure loss exposure faced by an organisation or an individual, and for the selection and implementation of the most appropriate techniques for treating such exposure. The process involves: identification, measurement, and management of the risk. Bessis (2010) also adds that in addition to it being a process, risk management also involves a set of tool and models for measuring and controlling risk. The objectives of risk management include to: minimise foreign exchange losses, reduce the volatility of cash flows, protect earnings fluctuations, increase profitability, and ensure survival of the firm (Fatemi and Glaum, 2000). According to Pyle (1997), risk management is the process by which managers satisfy these needs by identifying key risks, obtaining consistent, understandable, operational risk measures, choosing which risks to reduce, which to increase and by what means, and establishing procedures to monitor resulting risk positions.

Bessis (2010) indicates that the goal of risk management is to measure risks in order to monitor and control them, and also enable it to serve other important functions in a bank in addition to its direct financial function. These include assisting in the implementation of the bank's ultimate strategy by providing it with a better view of the future and therefore defining appropriate business policy and assisting in developing competitive advantages through the calculation of appropriate pricing and the formulation of other differentiation strategies based on customers' risk profiles.

According to Santomero (1995), the management of the banking firm relies on a sequence of steps to implement a risk management system. These normally contain four parts which are standards and reports, position limits or rules, investment guidelines or strategies, incentive contracts and compensation. These tools are generally established to measure exposure, define procedures to manage these exposures, limit individual positions to acceptable levels, and encourage decision makers to manage risk in a manner that is consistent with the firm's goals and objectives.

\subsection{Rationales for Risk Management in Banking}

The main aim of management of banks is to maximise expected profits taking into account its variability/volatility (risk). This calls for an active management of the volatility (risk) in order to get the desired results. Risk management is therefore an attempt to reduce the volatility of profit which has the potential of lowering the value of shareholders' wealth. Various authors including Stulz (1984), Smith et al (1990) and Froot et al (1993) have offered reasons why managers should concern themselves with the active management of risks in their organisations.

According to Oldfield and Santomero (1995), recent review of the literature presents four main rationales for risk management. These include managers' self-interest of protecting their position and wealth in the firm. It is argued that due to their limited ability to diversify their investments in their own firms, they are risk averse and prefer stability of the firm's earnings to volatility because, all things being equal, such stability improves their own utility. Beyond managerial motives, the desire to ensure the shouldering of lower tax burden is another rationale for managers to seek for reduced volatility of profits through risk management.

\subsection{Categories of Risk Management}

As Merton (1989) noted, a key feature of the franchise of financial institutions (including banks) is the bundling and unbundling of risks. However, not all risks inherent in their business should be borne directly by them; some can be traded or transferred whiles others can be eliminated altogether. It is therefore useful to defragment the risks inherent in their activities and assets into three distinctive subgroups in accordance with their nature so that the appropriate strategies can be adapted to mitigate them. Oldfield and Santomero (1995) argue therefore that risk facing financial institutions can be segmented into three 
separable categories from a management perspective. These are risks that can be eliminated or avoided by simple business practices, risks that can be transferred to other participants and risk that must be actively managed at the firm level.

\subsection{Key Bank Risks}

The risks associated with the provision of banking services differ by the type of service rendered. Different authors have grouped these risks in various ways to develop the frameworks for their analyses but the common ones which are considered in this study are credit risk, market risks (which includes liquidity risk, interest rate risk and foreign exchange risk), operational risks which sometimes include legal risk, and more recently, strategic risk.

\subsection{The Basel Committee}

The Basel Committee on the Banking Supervision (BCBS) develops risk management guideline for internationally active banks with the focus of ensuring resilience in the banking sector to protect economies. These recommendations which are issued by the $\mathrm{BCBS}$ are referred to as the Basel Accords as the BCBS maintains it secretariat at the Bank for International Settlement in Basel, Switzerland. Established by the central bank governors of the Group of Ten countries (G-10) in 1974 as a part of the Bank of International Settlement (BIS); the BCBS is arguably the most recognized organization in the field of banking supervision and risk management. The committee meets to address common issues affecting bankers all over the world. The BCBS has been developing standards and establishing frameworks for banks supervision towards strengthening financial stability which are applicable in the banking sectors around the globe. The aim of BCBS is to "formulate broad supervisory standards and guidelines and recommends statements of best practice in the expectation that individual authorities will take steps to implements them through detailed arrangements - statutory or otherwise - which are best suited to their own national systems".

In other words, BCBS tends to find the best common approaches and common standards for every member country in order to promote the advancement of risk management in the banking system, strengthen banking supervisory frameworks and to improve financial reporting standards. To achieve this goal, BCBS has published many documents in the field of capital adequacy, banking problems, accounting and auditing, core principles for effective banking supervision, credit risk and securitization, market risk, operational risk, money laundering and terrorist financing, transparency and disclosure. The reference points of BCBS's risk management recommendations are the Basel I, Basel II and Basel III accords.

\section{Methodology}

\subsection{Research Design}

The main approach to the study is by benchmarking. The study thus benchmarked the standard of the Ghanaian banking industry's risk profile to the recommendations of Basel Committee on Banking Supervision (BCBS); to assess the extent to which the banking sector in the country has gone so far with regards to the implementation of the Basel Accords. It brings out how the sector had adhered to the implementation according to the committee's time-table. It as well makes an inference from the analysis to conclude on whether the economy is at risk or not and if necessary base on to recommend measures for the strengthening of the mitigation measures to protect it. It also takes into consideration the banking act Act 673: 2004. It as well depended on the annual reports of the Bank of Ghana for data on the economy. It further makes use of the Ghana Banking Survey reports issue by PricewaterhouseCoopers Ghana in collaboration with Ghana Association of Bankers. The report gives a good comparative industry averages that serves as a useful data for the assessment of the trend of the sector's risk.

\subsection{Data Source}

The project makes use of secondary data as its main source of data. It relied on information put out by the Bank of Ghana in their periodic reports on the economy and the banking sector. Other sources of reliable data are industry watchers and financial analysts. Periodic reports of the PricewaterhouseCoopers reports, Ernst and Young, are the other sources the study sought reliable data to enhance its quality. Expert opinion based on limited unstructured interviews of some professionals allied to the field was used as qualitative check to confirm the realism of the available secondary data. This includes risk management expert and Internal Control professional in the industry.

\subsection{Tools for Analysis}

The study used the excel models quite extensively in the analysis of the data. This consist of spreadsheet-based data input tables that allows data to be collected and manipulated in consistent manner to provide authentic results. The spreadsheet provided for a big framework for the generation of graphs and determination of trends to support the assessment and evaluation as well as the interpretations of the data.

\section{Results and Discussion}

\subsection{Industry Profit}

The industry's balance sheet was generally profitable over the period with positive and significant growth in profit before tax. The sector recorded a profit before tax of 245.2 million in 2007 rising to GHs590 million in 2010 and 
maintaining the trend of growth to record a profit of 1.211 billion in 2012. The strong showing of the sector's profit before tax is a sustained assurance of improved Return on Asset (ROA) in the industry indicating a sound liquidity and cash flow to mitigate funding risk. At the same period the sector posted a strong position on Return on equity (ROE) to assure equity owners good returns on their investments thus attracting more stable capital into the sector to improve the Capital Adequacy Ratio. The sector recorded an average of $18.3 \%$ ROE between 2007 and 2012 . Profit after tax increased from $176.9 \mathrm{~m}$ in 2007 rising steadily to $902.3 \mathrm{~m}$ in 2012 .

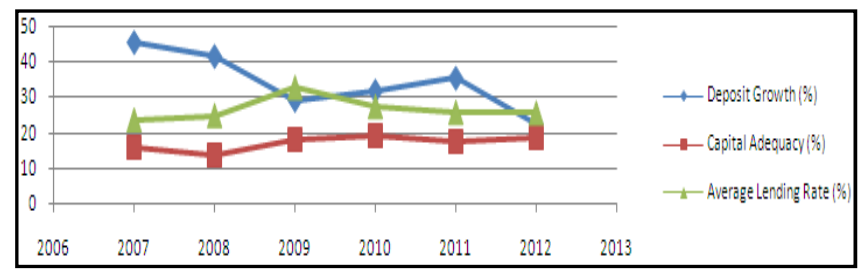

Figure 4.1. Deposit, capital adequacy, lending rate

\subsection{Total Assets}

Total assets maintain a steady growth throughout the period under consideration. It recorded a growth of $7.1 \%$ in 2007 rising to $17.4 \%$ in 2010 it maintained the momentum to end 2012 at a growth rate of $27.2 \%$. The massive improvement of capital as a result of the Bank of Ghana statutory recapitalization exercise has availed more funds for banks to improve on their business. The single obligor thresholds of banks have expanded for more flexible lending opportunities to improve on profitability. The improved CAR of the sector resulted in the banks' ability to book more risk assets over the period resulting in the profitability recorded at 4.1 .0 above.The industry was therefore, to a large extent, insulated from funding risk. And being the most secured loss-absorbing source of financing, the increased equity reduces the probability and severity of systematic risk in the sector

\subsection{Capital Adequacy Ratio}

From figure 4.0 above, the industry recorded a sound Capital adequacy ratio of 13.9 in 2008 increasing to 19.1 in 2010 before easing slightly to 17.4 in 2011 . It however resumed the rising trend in 2012 to $18.6 \%$. The rise in the CAR which saw the industry maintaining CAR far above the prudential limit of $10 \%$ over the period, is largely due to the effort of the banks to increase their capitals to meet the regulatory requirements by the December 2012 deadline. The industry thus had adequate capital to cover for contingent liabilities and increasing level of riskweighted assets on its books.

\subsection{Non-Performing Loans}

Whilst showing such resilience in CAR, the industry had over the period held quite high ratios on Non-Performing
Loans (NPL). The industry's NPL of $7.9 \%$ in 2008 rose to $13.2 \%$ in 2009 . It went up further to $16.2 \%$ in 2010 perhaps due to the decisive effort at tidying up the individual banks' credit portfolios in that year. The effort however resulted in a reduction of the NPL to $14.2 \%$ subsequently and further to $13.2 \%$ in 2012 . The trend of the NPL thus resulted in corresponding impairment charges of $1.5 \%$ in 2007 rising to $2.7 \%$ in 2008 and further to peak at $4.7 \%$ in 2010 to absorb the provision made in the loan portfolios before dropping to $2.3 \%$ in 2012 .

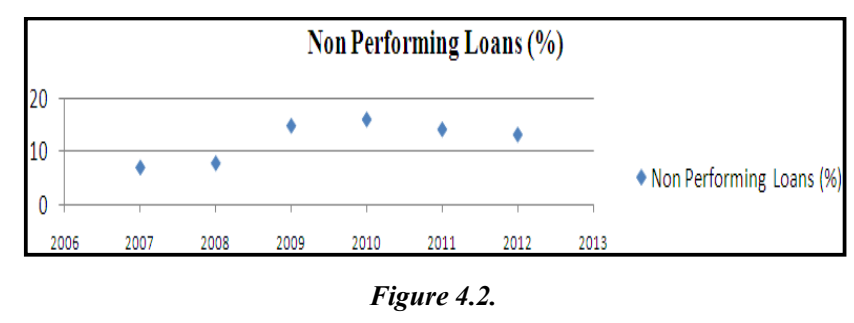

To help reduce the high default rate; to improve the general risk profile of the industry, the Bank of Ghana took a giant stride by instituting the Credit Reference Bureaux to help improve credit quality by making information on borrowers accessible to the industry to help ensure effective credit appraisal of clients prior to lending. To this effect, the Bank of Ghana licensed three companies XDS Data Ghana, Hudson Price Data Solution Limited and Dun and Bradstreet to operate as credit reference bureaux. The banks are gradually embracing the concept of credit reference bureau to improve on the quality of assets in the industry. By the close of 2011, all 26 universal banks had signed up to the credit reference services.

\subsection{Concentration Risk}

The over-concentration of sectoral distribution of credit portfolios exposed the industry to sectoral over exposure. The industry's credit is more concentrated in services and manufacturing sectors with fewer credits directed at areas like the agricultural sector. In 2010 and 2011, 35\% and 33\% respectively of the industry's loans and advancements were directed to commerce and financial sector. Within the same period only $4 \%$ and $6 \%$ went to Agriculture. The trend did not changed in 2012 perhaps due to challenges of lending to smallholder growers with limited credit history, unpredictable weather condition and market availability (PWC Banking Survey 2012). Whilst the measure may be a risk management strategy aimed at limiting credit exposure to a high risk area, it at the same time opens up the avenue for portfolio risk as most banks in the industry are relying on a few large corporate clients to build their loan portfolio. Any distress to these large clients could result in serious consequences for the industry.

\subsection{Policy Rate/ Inflation}

The policy rate was revised several times over the period to regulate the inflationary pressure in the economy. 
Inflation was volatile over the period and hence the Bank of Ghana needed to adopt monetary policies to control it. The Bank of Ghana thus adjusted the policy rate several times to mop up excess liquidity in the economy over the period. The average policy rate of $13.5 \%$ in 2007 rose to $17 \%$ in 2008. It went up further to peak in 2009 when it recorded $18 \%$ as inflation soured up. The policy rate which is based on the inflation thus dropped from $18 \%$ in 2009 to $13.5 \%$ and $12.5 \%$ in 2010 and 2011 respectively as inflation stabilized. It however picked up in 2012 to $15 \%$ as the economy started showing evidence of some distress with falling balance of trade and inflationary pressures increasing after the implementation of the new public sector wage policy with its consequential agitations on the labour front. Figure 4.3 illustrates the movement of inflation and policy rate between 2007 and 2012 .

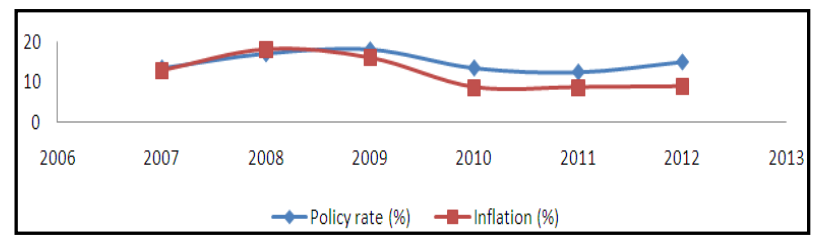

Figure 4.3. Policy Rate / Inflation

\subsection{Base Rate}

The average base rate in the industry thus followed a similar trend to the movement of the policy rate. From $21.5 \%$ in 2007 , the base rate moved up to 31.3 in 2009 easing up to $25.8 \%$ and further to 22.5 in 2010 and 2011 respectively, in responds to the reduction of the policy rate from $18 \%$ in 2009 to $12.5 \%$ in 2011 . Asset pricing similarly followed the trend rising from $25.02 \%$ in 2008 to 32.75 in 2009 and then easing up to $25.7 \%$ in 2012 . The industry however resisted consumer pressure to reduce the lending rate in response to the drastic reduction of the policy rate by the Bank of Ghana within the period citing high default rate as a factor in the computation of the lending rate. The volatility of the economic factors therefore created the market risks of effective pricing. That notwithstanding, the interrelationships amongst the three major risks therefore goes to imply that the high interest rates on loans exposes the industry to credit and operational risks as well.

Depreciation was a major source of market risks with regard to foreign exchange transactions. The cedi depreciated against the dollar in varying degrees over the period. There was therefore a serious currency mismatch risk in the industry over the period. International transaction was thus quite risky as the currency depreciated at the rate of $25.1 \%$ in 2008 and $17.7 \%$ in 2009 . With the commencement of the oil export from the country's new oil fields, the significant inflow of foreign exchange resulted in the stability of the cedi in 2010 and 2011. However the trend was reversed in 2012 as the cedi dipped by $17.5 \%$. The graph below shows the movement of the value of the cedi between 2007 and 2012 .

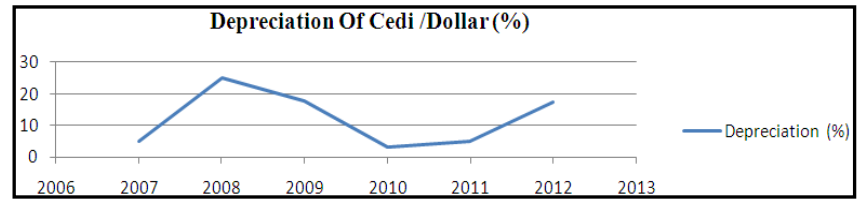

Figure 4.4.

Apart from the banking specific items like profit before tax, profit after tax, total assets, CAR and PNL which maintained positive growth trend, all other variables in the analysis saw a down turn in 2012. The trend suggests a high country and sovereign risks in the industry. Being an election year many individuals and organizations preferred to keep their funds in foreign currencies thereby boosting the pressure on the local currency to depreciate to a $17.7 \%$ from 2011's 5\%.The shift in preference against the cedi thus resulted in the depreciation of the cedi and the surge in inflation. Attention seems to have been diverted from the prudent economy management which hitherto was responsible for stability of the economy in 2010 and 2011. The country's balance of payment was reduced from 0.5 billion surplus in 2011 to a deficit of 1.5 billion in 2012 . There were more liquid funds in the economy outside the banking sector as growth in bank deposit dropped to $22.5 \%$ from the previous year's $35.3 \%$. The Bank of Ghana thus reacted by raising the policy rate from 12.5 in 2011 to $15 \%$ in 2012 to contain the resultant inflationary pressure in the economy. The weak performance of the Ghanaian economy in 2012, which follow a similar trend in 2008, is thus attributable to the country and sovereign risk emanating from uncertainty of the two years' elections.

\subsection{Operational Risk}

According to BCBS Operational Risk as the risk of loss resulting from inadequate or failed internal processes, people, and systems or from external events. Quantification and measurement of operational risk is difficult but it ranges from the commission and omission of internal staff, customers other external parties, the operating systems, the operational processes up to unsystematic risk arising out of acts of nature like earthquakes and fire outbreaks; which have the potential of causing loses to a bank. The Basel II accord gave equal prominence to operational risk as credit risk and market risks and stipulated how it could be assess and provided for. Operational risk has been observed to be critical to risk management in banks as most of the credit and market risks that affect banks invariably emanated from operational risk.

\subsection{Degree of Adherence}

Information gathered from PricewaterhouseCoopers' reports and confirmed by key-informants allied to risk management departments in the industry, the industry is presently operating by the Basel I accord. However, five years after the implementation schedule for the Basel accord II (2007-2012), the banking industry in Ghana is yet 
to implement the accord. Despite the zest with which the Bank of Ghana started the preparation of the banks towards the implementation of the accord, it mellowed on it along the way. The Bank of Ghana has postponed the implementation on a number of occasions. Meanwhile the industry is just eighteen months away from the recommended implementation schedule of the Basel III accord. One then wonders when the Basel II accord is going to be implemented to pave the way for preparation and subsequent implementation of the third accord. The situation presupposes that the industry is not well fortified as required and thus lags far behind the internationally active banks and hence could lower the risk profile of the sector in the face of the international business community. The sector is missing the all of the protection that comes with the Basel II accord. The elaborate operational risk management recommendations contain therein is yet to be implemented in the industry. With such high nonperforming assets in the industry as set out in 4.2.1 above, one would expect that the regulator would take steps to implement the accord to help stem the tide of the continuous deterioration of risk assets in the industry.

\subsection{Economic Growth}

The Ghanaian economy witnessed an impressive growth over the period under consideration. The economy grew at an average growth rate of $8.8 \%$ between 2007 and 2012 . From $6.2 \%$ in 2007 the economy attained its all-time highest growth of $14.9 \%$ in 2011 partly due to the contribution of the oil sub-sector. The rate of growth however dipped to $6.8 \%$ in 2012 possibly as a result of the electioneering activities of the year which diverted a lot of attention from economic activities to politics. In general the average growth rate of $8.8 \%$ over the period makes the economy one of the fastest growing economies in Africa. It attained a middle income economic status in 2010 when the statistical services department rebased the economy to reflect the real economic development. The figure below illustrates the trend of economic growth over the period.

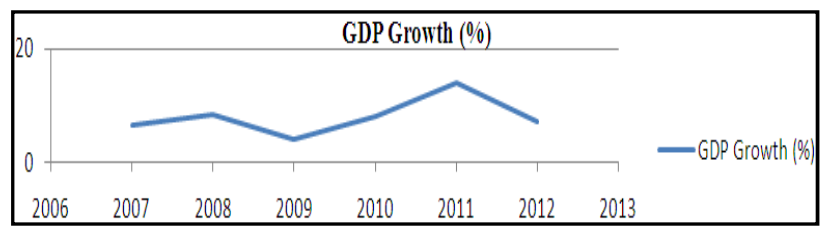

Figure 4.5.

The strong performance of the economy resulted in favourable balance of payment over the period recording 0.413 billion dollar trade surplus in 2007 with an increasing trend to attain 1.5 billion dollars in 2010. The trend then saw a downwards growth; reversing to $\$ 547$ billion dollars and a whopping 1.2 billion balance of payment deficit in 2012. The reduction in the economic growth and the corresponding reduction in the country's trade balance in the elections year is a pointer to a serious political risk for the country's banking sector.

From the analysis of the data in the previous chapter, it came out clearly that the macro-economic indicators are pointing to a favourable economy with high growth prospects. There is no doubt that one of the main pillars that are supporting the economy is the banking sector. Any infractions in the management of the sector could thus have serious consequences on the economy. Although the Bank of Ghana has been watchful of the sector, the degree of inherent risk in the industry is a potential risk to the national economy. The constant report of fraud and the ineptitude of staff as well as such breaches of regulations as was reported of the Access bank(GNA Report, July 24. 2012); are some potential sources of unsystematic risk that can spring surprises on the industry to rake havoc on the economy.

\section{Conclusion and Recommendations}

In sum, it is clear from the data analysis of the last six year span (2007-2012) that the banking industry in Ghana does not have a very good risk profile. It could have been better if the BCBS accord had been implemented as it seeks to improve on the individual banks profiles for the collective good of the economy. Just as some economies have fallen as a result of banking crisis, the Ghanaian economy is exposed to potential risks from its banking sector.

Base on the findings of the study, it is recommended to the Bank of Ghana to take steps to implement the Basel II accord in the industry as soon as possible and possibly meet the implementation schedule of the Basel III accord, to improve on the sector's risk profile locally and internationally. The recommendation in the Basel II contain excellent risk management framework which if implemented could go a long way to strengthen the sector's risk profile to protect the economy and to enlist the confidence of the international business community in the sector. It is also recommended that in situations of punitive measure must be taken against the culprit to serve as a deterrent to the rest of the banks in the industry.

\section{References}

[1] Basel Committee on Banking Supervision (1999), Principles for the Management of Credit risk II , Bank for International Settlements, Basel.

[2] Basel Committee on Banking Supervision (2001), Principles for the Management and Supervision of Interest Rate Risk \|, Bank for International Settlements, Basel.

[3] Basel Committee on Banking Supervision (2003), Sound Practices for the Management and Supervision of Operational Risk, Bank for International Settlements, Basel.

[4] Basel Committee on Banking Supervision (2003), Trends in risk integration and aggregation, Bank for International Settlements, Basel. 
[5] Basel Committee on Banking Supervision (2006), Corporate Governance for Banking Organizations (Enhancing Corporate Governance for Banking Organizations), Bank for International Settlements, Basel.

[6] Basel Committee on Banking Supervision (2008), Principles for Sound Liquidity Risk Management and Supervision \|, Bank for International Settlements, Basel.

[7] Bessis, J. (2010), Risk Management in Banking, Wiley, Third edition.

[8] Böblingan, J.G. (2008) "The Risks of Financial Risk Management", Master's Thesis, Zeppelin University.

[9] Fatemi, A. \&Glaum, M. (2000), Risk management practices in German firms $\|$, Managerial Finance, 26, 1-17.

[10] Froot, K. A., Scharfstein, D. S., \& Stein, J. C. (1994), A Framework for Risk Management II , Harvard Business Review, 76(6), pp. 91-102.

[11] Oldfield, G. \&Santomero A. M. (1995), The Place of Risk
Management in Financial Institutions \|, Wharton Financial Institutions Center, University of Pennsylvania, Working Paper 95-05-B.

[12] Pyle, D. H. (1997) "Bank Risk Management: Theory," Institute of Business and Economic Research, University of California, Finance Working Paper No. RPF-272, July 1997.

[13] Rejda, G. E. (1998), Principles of risk management and insurance, USA: Addison Wesley, Sixth Edition, New York, NY.

[14] Santomero, A.M. (1995) "Financial Risk Management: The Whys and Hows," Financial Markets, Institutions and Instruments 4(5):1-14.

[15] Schmit, J. T. \& Roth K. (1990), "Cost Effectiveness of Risk Management Practices," Journal of Risk and Insurance, Vol. 57, No.3 pp. $455-470$

[16] Stulz, R. M. (1984), Optimal Hedging Policies \|, The Journal of Financial and Quantitative Analysis, Vol. 19, No. 2. pp. 127-140. 